\title{
A multi-perspective examination of the barriers to field- placement experiences for students with disabilities
}

\author{
Tara Flanagan, Fiona J Benson, Frederic Fovet, McGill University
}

\section{Introduction}

Changes are occurring rapidly within Higher Education to include real-world experiences and evaluations as core components of professional programs (Zunker, 2006). This new focus on providing more opportunities for learning in authentic community settings is thought to promote better pedagogy by focusing on multiples perspectives and areas of expertise (Zeichner, 2010) and to increase opportunities in the workplace by promoting practical and flexible skills that are essential in the field (Bogo, 2010; Buhai, 1999; Dreuth \& Dreuth-Fewell, 2002; Getzel, 2008). This emerging shift in curricular foci is co-occurring with changes in the demographic composition of the student body in most post-secondary institutions. On the whole, campuses are becoming more inclusive and are increasingly welcoming students from a variety of backgrounds and with different types of disability.

Historically, students with disabilities were considered to be the responsibility of a dedicated "office for students with disabilities" where they received services and accommodations. Unfortunately, this model created the view that there is a unified endpoint and approach to disability service provision. It is misguided to conclude that disability service provision is unchanging, context-independent, and an island unto itself. Research on different models of service provision suggest that students with disabilities tend to fare better in postsecondary environments that implement a Universal Design approach where multiple stakeholders are responsible for meeting the needs of a diverse student body (Getzel, 2008; Lightfoot \& Gibson, 2005). Student profiles, perspectives, and expectations are changing as rapidly as the demands in the field and of community partners (Pardeck, 2002). This new focus on real world experiences in post-secondary education challenges the traditional philosophies of service provision and provides an opportunity for reflection and change (Tynja"la“, Va"limaa \& Sarja, 2003). As we increasingly embrace the Social Model of Disability in higher education where we discuss external barriers to education and access and where environment-focused models such as Universal Design become implemented (Gradel \& Edson, 2010), we should be asking whether environmental barriers continue into real-world contexts (Burgstahler, 2008). The notion of a smooth, seamless transition to the field for students with disabilities seems utopic (Harrison\& Ip, 2012). Yet, the current models of service provision and teaching and learning seem to poorly prepare students for this complex transition. It is this frustrating observation that led us to come together on a collaborative brainstorming project regarding field placements for students with disabilities.

We asked ourselves: Are traditional access solutions in line with the demands in the real world? Are field placements, the focal connection point between academic and professional worlds any less fraught with access issues than traditional approaches to education? Do traditional access solutions meet the needs of students with disabilities and/or of field and community partners? 


\section{Context}

Though there is a general paucity of data on this topic, the research that is available focuses on the perspectives of field supervisors who tend to report on the numerous barriers that seem to be present in the field for students with disabilities. For example, Alperin (1988) queried more than 300 directors of fieldwork in accredited Social Work programs to conclude that almost $60 \%$ reported barriers related to transportation and/or to acceptance within the agencies where their students were placed. Reeser (1992) interviewed 12 field placement supervisors in Social Work who reported on the rampant systemic discrimination, inflexibility, and prejudice that created barriers for their field placement students with disabilities. In response to this situation, scholars in the area are calling for a collaborative effort to engage all stakeholders in the process of defining criteria for excellence in field placement components of academic programs (Buhai, 1999; Cole, Christ \& Light, 1995), to be proactive during the pre-placement phase (Alperin, 1988), and to form effective partnerships between academic and community partners that have a mandate of promoting equity (Reeser, 1992).

To better illustrate our contention that the current models of service provision and teaching and learning seem to poorly prepare students for this complex transition from program to field, we share some of the challenges faced by the current field service component of the university teacher preparation program that falls under the purview of the Office of Student Teaching (OST). The OST has based its evolution over the past decade on models of excellence in the educational milieu (Beck \& Kosnik, 2006; Cochran - Smith, Feiman - Nemser, \& McIntyre, (Eds.), \& Demers, (Assoc. Ed.), 2008; Cochran-Smith \& Zeichner, 2005; DarlingHammond, 2006) - and recognizes that, in the words of Darling-Hammond, the practical fieldBased component of any teacher preparation program is "the glue for powerful preparation" (2006, p. 152).

In the past five years, the OST has seen an upsurge in the number of pre-service teachers with disclosed and undisclosed disabilities placed in field experiences which are largely evaluated by school partners (cooperating or associate teachers) who may or may not be familiar with, or receptive to, the needs of these students. This phenomenon is due in part to the limited information regarding how best to accommodate these more nuanced and flexible skills in the field, if at all (Benson, Fovet, \& Flanagan, 2013). The OST is acutely aware of, and proactive in responding to, the requirement for the provision of professional development within school communities to integrate and support increasing numbers of student teachers who present with a range of disability and difference (Watkinson \& Chalmers, 2008).

\section{Data Collection and Observations}

Our research project, prompted by our own observations of the barriers to equity for field placement students with disabilities at our institution, is an attempt to reflect on our disability service and teaching and learning practices. We wanted to expand on the focus of the available research by: 1) creating a multi-dimensional cross-sector collaboration between a faculty member in Educational Psychology, the Director of the Office for Student Teaching (OST), and the Director of the Office for Students with Disabilities (OSD); and, 2) including the perspectives of Professional Program Directors $(n=5)$, Field Placement Coordinators $(n=26)$, and students with disabilities $(\mathrm{n}=29)$. 


\section{Professional Program Directors}

Program Directors from a variety of professional programs reported on their observations regarding barriers to successful field placements for students with disabilities. Our qualitative data highlight that professional program directors feel overwhelmed and disempowered, and that they generally view the barriers from a Medical Model perspective (i.e., as being inherent to the individual). There is also a tangible fear that the growing friction caused by access issues may lead to the loss of some field partners and of a narrowing of opportunities for the students in their respective programs. The following are some illustrative anecdotal comments collected from

\section{Program Directors}

"Every year students seem to present more and more with disabilities especially mental health and learning disabilities which affects their work and ability to function in the field."

"...good time management is required which may be an issue for some."

"... sometimes they ask to not be placed in hospital settings...but we can't accept such requests..."

\section{Field Placement Coordinators}

Similarly, we asked Field Placement Coordinators about the barriers to successful field placements for students with disabilities. This group also seemed to be struggling to find effective solutions, tended to be unsure about the legal components of the process (e.g., protections afforded to students with disabilities in matters such as disclosure), and erred on the side of exclusion. The following are some of the anecdotal comments that were recorded: "our mentoring must include forming a relationship that facilitates his/her field experience." "I believe that Field Supervisors should be sensitized to the student's disability..."

"Disclosure. Extra support visits."

"Place them in an appropriate setting so that they can succeed."

"I do not feel that all disabilities can be adapted to the teaching profession."

\section{Students with Disabilities}

We explored the perspectives of students with disabilities through quantitative and qualitative techniques. We found that students with disabilities largely feel underprepared for their professional field placements, experience or expect to be experiencing barriers in their field placements and then in the world of employment upon graduation. In a recent quantitative poll of 61 students with disabilities from the OSD who were participating in or preparing for field placements, 50\% reported either experiencing or fearing barriers in field placements and $48 \%$ reported that they had concerns about barriers in employment upon graduation. Table 1 depicts the responses to a follow-up question geared at this subsection of the 61 respondents $(\mathrm{N}=29)$ who indicated that they were concerned about barriers in employment. $72 \%$ of whom reported being concerned about the barriers, $45 \%$ reported that they were anticipating the barriers to be the same as at the university, and $66 \%$ expected new barriers to emerge in employment environments. Unfortunately, only $17 \%$ reported receiving any kind of support to prepare for the transition into employment and the anticipated barriers. 
Table 1 Percentage of respondents who identified with the following statements

\section{Q21. Which of the following statement(s) apply to you? (Check all that apply)}

\begin{tabular}{|l|l|l|l|}
\hline $\mathbf{N}$ & $\begin{array}{l}\% \\
\text { Respondents }\end{array}$ & & \\
\hline $\mathbf{1 3}$ & $45 \%$ & $\begin{array}{l}\text { I believe the barriers in employment will be the } \\
\text { same as I am experiencing at the university. }\end{array}$ \\
\hline $\mathbf{1 9}$ & $66 \%$ & I expect to experience new barriers in employment. \\
\hline $\mathbf{2 1}$ & $\mathbf{7 2 \%}$ & I have concerns about barriers in employment. \\
\hline $\mathbf{5}$ & $17 \%$ & I am currently receiving support to prepare for or to \\
\hline $\mathbf{2 9}$ & $\begin{array}{l}\text { Total } \\
\text { Respondents }\end{array}$ & of & \\
\hline
\end{tabular}

Additional qualitative data were collected through ongoing dialogue between the students with disabilities and access advisors at the OSD. These data were analyzed for common themes and highlight the following issues: 1) students with disabilities are generally not focusing on nor preparing for the changing nature of the environment as they embark on field placements; 2) students report feeling that access issues are no longer the responsibility of the OSD once they enter the field even though they continue to be enrolled in field placements as part of an academic program; 3) students often report experiencing additional barriers in accessing support services during the field placement component of their programs (e.g., restricted opening hours, geographical distance from campus, and lack of perceived connections between disability unit and the field environment).

\section{Informing models of teaching and learning}

Our findings regarding the field placement experiences of students with disabilities highlight the need to explore solutions from a variety of perspectives and to revisit and revolutionize our approaches to disability service provision and to teaching and learning in order to meet the needs of students and of field partners. All of the stakeholders who participated in this query reported barriers to success for field placement students with disabilities, saw few solutions, and anticipated the barriers to continue into the world of employment. It seems clear that the traditional approaches to teaching and learning and to disability service provision are missing the mark with regard to supporting all students in their quest to attain equitable real-world experiences that open doors to meaningful employment opportunities.

It is important to collectively resolve to promote equity and inclusion both on campus and in our community partnerships (Alperin, 1988; Buhai, 1999; Cole, Christ \& Light, 1995; Reeser, 1992). This study provides a precious example of cross-disciplinary collaboration. Occasions when student service personnel collaborate with faculty members on research projects and share their insights into service provision and teaching and learning are far too rare. This has been a hugely enjoyable process for the collaborators in this study and we sincerely hope that others 
will feel compelled to collaborate on this type of research using field placements as the catalyst for evaluation and significant change in their post-secondary institutions.

\section{References}

Alperin, D.E. (1988). The physically disabled BSW student. Journal of Teaching in Social Work, 2, 99-111.

Beck, C., \& Kosnik, C. (2006). Innovations in teacher education: A social constructivist approach. New York: State University of New York Press.

Benson, F., Fovet, F., \& Flanagan, T. (2013, June). Easing transitions from program to field for students with disabilities. Paper accepted at the Society for Teaching and Learning in Higher Education (STLHE), Cape Breton, NS.

Bogo, M. (2010) Achieving Competence in Social Work through Field Education. Toronto, Canada: University of Toronto Press.

Budhai, S.L. (1999). Practice makes perfect: Reasonable accommodation of Law students with disabilities in clinical placements. San Diego Law Review, 36, 137-194.

Burgstahler, S.E. (2008). Universal design in higher education. In S.E. Burgstahler \& R.C. Cory (Eds.), Universal design in higher education: From principles to practice (pp. 3-20). Cambridge, MA: Harvard Education Press.

Cochran - Smith, M., Feiman - Nemser, S., \& McIntyre, J. (Eds.), and Demers, K. (Assoc. Ed.). (2008). Handbook of research on teacher education: Enduring questions in changing contexts $\left(3^{\text {rd }}\right.$. ed.). NewYork: Routledge.

Cochran-Smith, M., \& Zeichner, K.M. (2005). Studying teacher education: The report of the AERA panel on research and teacher education. Mahwah, N.J: Lawrence Erlbaum Associates.

Cole, B.B., Christ, C.C., \& Light, T.R. (1995). Social Work education and students with disabilities: Implications of section 504 and the ADA. Journal of Social Work Education, 31, 261-268.

Darling-Hammond, L. (2006). Powerful teacher education: Lessons from exemplary programs. San Francisco: Jossey-Bass.

Dreuth, L. \& Dreuth-Fewell, M. (2002). A model of student learning in community service field placements. Learning in Higher Education, 3, 251-264.

Getzel, E.E. (2008). Addressing the persistence and retention of students with disabilities in higher education: Incorporating strategies and support on campus. Exceptionality: $A$ Special Education Journal, 16, 207-219. 
Gradel, K. \& Edson, A.J. (2010). Putting universal design for learning on the higher ed agenda. Journal of Educational Technology Systems, 38, 111-121.

Harrison, G., \& Ip, R. (2012). Extending the terrain of inclusive education in the classroom to the field: International students on placement, Social Work Education: The International Journal, 32, 230-243.

Lightfoot, E., \& Gibson, P. (2005). Universal Instructional Design: A new framework for accommodating students in social work courses. Journal of Social Work Education, 41, 269277.

Pardeck, J.T. (2002) A commentary on the admission and retention of students with disabilities in social work programs, Journal of Social Work in Disability and Rehabilitation, $1,3-13$.

Reeser, L.C. (1992). Students with disabilities in practicum: What is reasonable accommodation? Journal of Social Work Education, 28, 98-109.

Tynja"la", P., Va"limaa, J. \& Sarja, A. (2003) Pedagogical perspectives on the relationship between higher education and working life, Higher Education, 46, 147-166.

Watkinson, A. M., \& Chalmers, D. (2008). Disability, professional unsuitability and the profession of Social Work: A case study, Montréal, QC : CREPUQ.

Zeichner, K. (2010). Rethinking the connections between campus courses and field experiences in college- and university-based teacher education. Journal of Teacher Education, 61, 89-99.

Zunker, V.G. (2006). Career counseling: A holistic approach (7th ed.). Pacific Grove, CA: Brooks/Cole. 